CZASOPISMO INŻYNIERII LADDOWEJ, ŚRODOWISKA I ARCHITEKTURY

\title{
STATECZNOŚĆ MIMOŚRODOWO ŚCISKANEJ ŚCIANKI WSPORNIKOWEJ ELEMENTU CIENKOŚCIENNEGO
}

\begin{abstract}
W pracy zamieszczono wyniki badań stateczności mimośrodowo ściskanych ścianek wspornikowych stanowiących części składowe elementów cienkościennych. Ścianki takie charakteryzują się dużymi smukłościami i są wrażliwe na lokalną utratę stateczności. W celu rozwiązania zadania zastosowano model cienkiej płyty wspornikowej. Funkcję ugięcia zapisano w postaci szeregu wielomianowo - sinusowego. Uwzględniono warunki sprężystego zamocowania przeciw obrotowi oraz różne rozkłady naprężeń (wg funkcji stałej, liniowej i paraboli 2. stopnia) na długości elementu. Naprężenie krytyczne odniesiono do najbardziej ściskanej krawędzi dla danego przypadku obciążenia. Współczynniki wyboczeniowe $k$ wyznaczono metodą energetyczną. Pokazano wykresy współczynnika $k$ dla takich przypadków obciążenia, których nie znaleziono w literaturze. Wyprowadzono wzory aproksymacyjne współczynnika $k$ dla stałego na długości płyty rozkładu naprężeń. We wzorach uwzględniono różne przypadki mimośrodowego ściskania w funkcji wskaźnika sprężystego utwierdzenia. Omówiono sposoby oszacowania współczynnika $k$ dla pośrednich wartości parametrów oraz przedstawiono prostą formułę przybliżoną dla długich płyt wspornikowych. Sposób wykorzystania wzorów aproksymacyjnych pokazano w przykładzie obliczeniowym. Stwierdzono, że uwzględnienie sprężystego zamocowania krawędzi ścianki (płyty) wspornikowej w segmencie pręta cienkościennego oraz poprzecznej i wzdłużnej zmienności naprężeń prowadzi do precyzyjniejszego wyznaczenia naprężeń krytycznych wyboczenia lokalnego. Poprawia to dokładność odwzorowania zachowania się elementu cienkościennego w inżynierskim modelu obliczeniowym. Tak wyznaczone naprężenia krytyczne mogą także posłużyć do dokładniejszego wyznaczenia szerokości współpracujących różnie obciążonych ścianek wspornikowych.
\end{abstract}

Słowa kluczowe: pręty cienkościenne, przekrój otwarty, płyty wspornikowe, sprężyste zamocowanie, wzdłużna zmienność naprężeń

\footnotetext{
1 Autor do korespondencji: Andrzej Szychowski, Politechnika Świetokrzyska w Kielcach,
} Al. Tysiąclecia Państwa Polskiego 7, 25-314 Kielce, tel: 41 3424575, -mail: aszychow@tu.kielce.pl 


\section{Wprowadzenie}

Współcześnie stosowane prętowe elementy cienkościenne charakteryzują się dużymi smukłościami ścianek składowych. Są zatem wrażliwe na różne postacie wyboczenia lokalnego i/lub dystorsyjnego.

W złożonych stanach obciążenia (np. przy ściskaniu i zginaniu lub nieswobodnym skręcaniu pręta cienkościennego) w płaskich ściankach wspornikowych może występować mimośrodowe ściskanie przy różnym rozkładzie naprężeń na długości segmentu pręta $\left(l_{s}\right)$. Segment pręta cienkościennego zdefiniowano $\mathrm{w}$ [5] jako odcinek pomiędzy usztywnieniami poprzecznymi (żebrami, przeponami itp.) zapewniającymi sztywny kontur przekroju. Taka definicja jest szczególnie istotna w przypadku wzdłużnej zmienności naprężeń, gdyż występują wówczas złożone postacie utraty stateczności [8]. Ścianka wspornikowa może stanowić np. półkę kształtownika cienkościennego, pojedyncze odgięcie usztywniające kształtownika giętego lub płaski element usztywniający konstrukcji blachownicowej. Klasyczne przykłady występowania ścianek wspornikowych pokazano na rys.1a.

a)

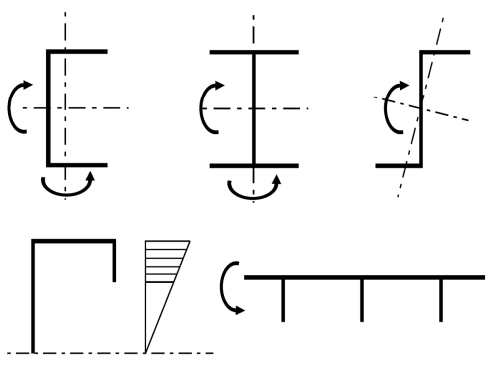

b)

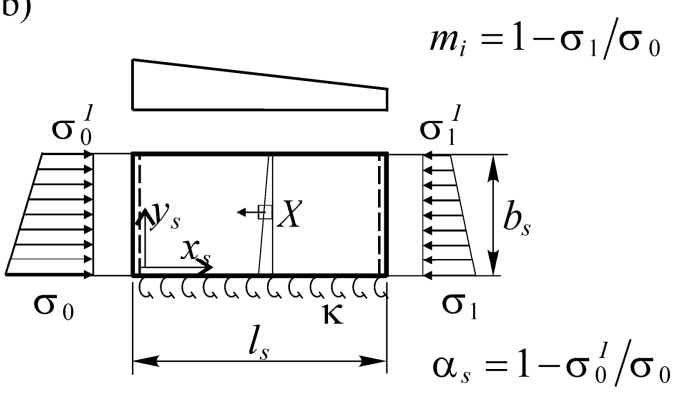

Rys. 1a) Przykłady ścianek wspornikowych, b) wydzielona z elementu cienkościennego ścianka wspornikowa

Fig. 1a) Examples of cantilever walls, b) cantilever wall isolated from a thin-walled member

Ponieważ ścianki wspornikowe charakteryzują się znacznie mniejszą odpornością na naprężenia ściskające w stosunku do ścianek przęsłowych, stanowią na ogół ściankę słabszą (podpieraną), decydującą o lokalnej utracie stateczności całego przekroju. W takim przypadku ścianka wspornikowa jest sprężyście zamocowana przeciw obrotowi w ściance przęsłowej (np. półka zamocowana $\mathrm{w}$ środniku lub usztywnienie brzegowe zamocowane w półce, por. rys.1.), dla której obie krawędzie wzdłużne są podparte.

W normach $[13,14,15]$ do uwzględnienia wyboczenia lokalnego pręta cienkościennego o przekroju klasy 4 przyjęto model obliczeniowy separacji ścianek (płyt składowych) polegający na ich swobodnym podparciu na podłużnych krawędziach łączenia. W tym podejściu, o naprężeniach krytycznych z warunku 
wyboczenia lokalnego decyduje najsłabsza ścianka, na którą nie oddziałują ścianki sąsiednie. Jedynie w przypadku odgięcia usztywniającego, w normie [14] przyjęto uproszczony schemat sprężystego zamocowania ścianki wspornikowej w półce przekroju, pozwalający na przyjęcie wyższej wartości współczynnika $k$ (np. $0.5 \mathrm{w}$ miejsce 0.43 ). W rzeczywistych elementach cienkościennych występuje sprężyste zamocowanie ścianek sąsiednich, co może być uwzględnione w modelu obliczeniowym [8].

W wielu technicznie ważnych przypadkach lokalne wyboczenie elementu cienkościennego jest wywołane utratą stateczności ścianki najsłabszej (,krytycznej"), która po wyboczeniu wymusza deformacje sąsiednich ścianek. Oczywiście istnieją przekroje, dla których w określonych stanach naprężenia wszystkie ścianki są „krytyczne”, tzn. decydują o utracie stateczności całego przekroju (np. osiowo ściskany kwadratowy przekrój skrzynkowy). To sprężyste zamocowanie przeciw obrotowi ścianki najsłabszej, wynikające ze sprężystego połączenia ze ścianką mocniejszą (podpierającą), podnosi jej naprężenia krytyczne. Efekt ten wykorzystuje się dotychczas jedynie we wspomnianym już przypadku odgięcia krawędzi oraz $\mathrm{w}$ analizie wyboczenia dystorsyjnego kształtowników formowanych na zimno [14]. W tym przypadku ściankę $\mathrm{z}$ odgięciem (tj. ich szerokości współpracujące) traktuje się jako zastępczy pręt ściskany na podłożu sprężystym. Moduł sprężystości podłoża $(K)$ wyznacza się w zależności od sztywności obrotowej $\left(C_{\theta}\right)$ krawędzi podpartej (na którą wpływa sztywność zginania ścianki podpierającej i jej stan naprężenia) oraz sztywności zginania samej ścianki.

Lokalne wyboczenie elementu cienkościennego o przekroju otwartym, inicjowane np. przez mimośrodowo ściskaną ściankę wspornikową, można w praktyce uwzględniać w oparciu o analizę stateczności płyty wspornikowej sprężyście zamocowanej w płycie podpierającej. W przypadku płyty wspornikowej, naprężenia krytyczne wyboczenia lokalnego zależą od jej smukłości, poprzecznego i wzdłużnego rozkładu naprężeń oraz stopnia sprężystego zamocowania krawędzi podpartej. Poprawne wyznaczenie naprężeń krytycznych dla tak podpartych i obciążonych ścianek (płyt składowych) pręta cienkościennego służy do dokładniejszego oszacowania nośności granicznej przekroju metodą szerokości współpracującej.

W monografii [1] podano wykresy i wzór aproksymacyjny współczynnika $k$ dla osiowo ściskanej płyty wspornikowej przy stałym rozkładzie naprężeń na jej długości w funkcji współczynnika sprężystego zamocowania $(\varepsilon)$ wg wzoru:

$$
\varepsilon=C_{\theta} b_{s} / D_{s}
$$

gdzie: $C_{\theta}$ - sztywność obrotowa krawędzi podpartej równa momentowi zginającemu powstałemu podczas obrotu o kąt jednostkowy, $b_{s}$ - szerokość płyty ulegającej wyboczeniu, $D_{s}=E t_{\mathrm{s}}^{3} /\left(12\left(1-v^{2}\right)\right)$ - płytowa sztywność zginania. 
W pracy [12] analizowano m.in. wpływ wzdłużnej zmienności naprężeń (rozkład naprężeń wg funkcji liniowej) na stateczność osiowo ściskanych płyt wspornikowych dla granicznych warunków brzegowych (przegub, utwierdzenie) na krawędzi podpartej. Dla tych przypadków podparcia i obciążenia zaproponowano przybliżoną formułę obliczania współczynnika $k$.

W pracy [5] przedstawiono wyniki badań stateczności mimośrodowo ściskanych płyt wspornikowych przy wzdłużnej zmienności naprężeń dla granicznych przypadków podparcia krawędzi podłużnej (przegub lub utwierdzenie). Wyprowadzono wzory na pracę sił zewnętrznych przy obciążeniu wywołującym wzdłużny rozkład naprężeń wg funkcji liniowej oraz wg paraboli 2. stopnia. $Z$ kolei w pracy [6] przedstawiono wykresy współczynnika $k$ sprężyście zamocowanych ścianek wspornikowych dla wybranych przypadków wzdłużnej i poprzecznej zmienności naprężeń w przedziale: $1.5 \leq \gamma_{s} \leq 8$, gdzie $\gamma_{s}=l_{s} b_{s}$. Natomiast $\mathrm{w}$ pracy [8] wyprowadzono wzory aproksymacyjne współczynnika $k$ dla osiowo ściskanej płyty wspornikowej dla dowolnego stopnia sprężystego zamocowania krawędzi podpartej oraz dowolnie „nachylonego" na długości płyty rozkładu naprężeń wg funkcji liniowej i paraboli 2. stopnia. Dla wzdłużnej zmienności naprężeń zdefiniowano „półfalę krytyczną”, jako tę z największymi ugięciami i występującą w obszarze największych naprężeń. Za jej długość wyboczeniową $\left(l_{c r}\right)$ przyjęto, podobnie jak dla stałej intensywności naprężeń $\left(m_{i}=0\right.$, gdzie $m_{i}$ wg rys.1b), odległość pomiędzy punktami przegięcia $\left(w^{I I}\left(x_{s}\right)_{y=b}=0\right.$, gdzie $w\left(x_{s}\right)$ - funkcja ugięcia płyty), ,śladu" pierwszej postaci wyboczenia o maksymalnych przemieszczeniach i występującej od strony maksymalnych obciążeń.

W celu dokładniejszego rozwiązania wielu zagadnień wyboczenia lokalnego oraz nośności granicznej (szacowanej wg metody szerokości współpracującej) otwartych prętów cienkościennych w złożonych stanach naprężenia, należy uzupełnić wybrane rozwiązania stanu krytycznego ścianek składowych. Chodzi tutaj o mimośrodowo ściskane ścianki (płyty) wspornikowe, przy jednoczesnym uwzględnieniu zarówno sprężystego zamocowania przeciw obrotowi krawędzi podpartej, jak również wzdłużnej zmienności naprężeń. W normie [5] podano jedynie wzory współczynników $k$ dla swobodnie podpartej płyty (ścianki) wspornikowej z uwzględnieniem poprzecznej zmienności naprężeń. Jak wykazano w pracach $[5,6,8]$, w takich ściankach występują zapasy lokalnej nośności krytycznej w stosunku do modelu obliczeniowego separacji ścianki podpartej przegubowo, który przyjęto w normach $[13,14,15]$.

W niniejszej pracy wyznaczono współczynniki $k$ dla sprężyście zamocowanych i mimośrodowo ściskanych płyt wspornikowych przy występowaniu technicznie ważnych schematów obciążeń, których nie znaleziono w literaturze i nie zamieszczono w pracach $[5,6,8]$. Ponadto wyprowadzono wzory aproksymacyjne dla różnych poprzecznych rozkładów naprężeń umożliwiające wyznaczenie współczynnika $k$ dla $m_{i}=0$ oraz oszacowanie $k$ dla pośrednich wartości parametru $m_{i} \mathrm{z}$ przedziału (0-1). Zaproponowano także uproszczoną procedurę szacowania $k$ dla długich płyt (ścianek) w przedziale: $8 \leq \gamma_{s} \leq 50$. 
$\mathrm{Na}$ rysunku 2. pokazano rozpatrywane $\mathrm{w}$ niniejszej pracy przypadki poprzecznej zmienności naprężeń w płycie wspornikowej w zależności od wartości parametru $\alpha_{s}$ (por.rys.1). Dla porównania, jako pierwszy pokazano klasyczny przypadek osiowego ściskania dla $\alpha_{s}=0$.

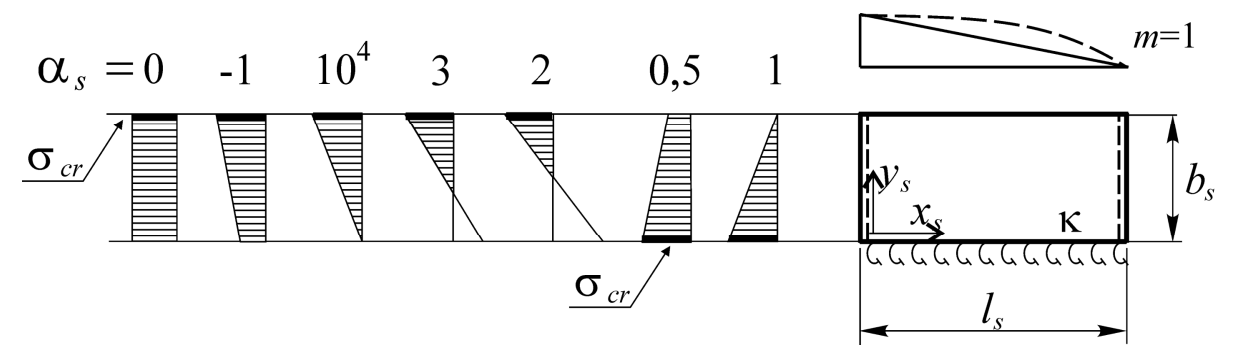

Rys. 2. Rozpatrywane schematy rozkładu naprężeń w płycie wspornikowej

Fig. 2. Considered patterns of stress distributions in the cantilever plate

\section{Warunki brzegowe płyty wspornikowej}

Założono, że: 1) ścianka wspornikowa przekroju cienkościennego zachowuje się jak płyta wspornikowa, sprężyście zamocowana przeciw obrotowi w płycie sąsiedniej np. w środniku, 2) druga krawędź podłużna jest swobodna i nie zawiera usztywnienia krawędziowego; 3) mimośrodowe ściskanie płyty występuje jedynie w jej płaszczyźnie; 4) poprzeczne krawędzie płyty przyjęto jako swobodnie podparte; 5) rozpatruje się naprężenia $\mathrm{w}$ zakresie sprężystym.

Stopień sprężystego zamocowania podłużnej krawędzi płyty $\left(y_{s}=0\right)$ opisano za pomocą współczynnika zamocowania $\varepsilon$ wg wzoru (1) [1] oraz wskaźnika sprężystego utwierdzenia $\kappa$ wg [4] w następującej postaci:

$$
\kappa=1 /\left(1+2 D_{s} / b_{s} C_{\theta}\right)
$$

Współczynnik $\varepsilon$ wg wzoru (1) zmienia się od $\varepsilon=0$ dla podparcia przegubowego do $\varepsilon=\infty$ dla utwierdzenia, natomiast wskaźnik $\kappa$ wg wzoru (2), od $\kappa=0$ (przegub) do $\kappa=1$ (utwierdzenie), przy czym $\kappa=\varepsilon /(2+\varepsilon)$.

Sztywność obrotową podpartej krawędzi płyty wspornikowej można wyznaczyć ze wzoru:

$$
C_{\theta}=\frac{\eta D_{r}}{b_{r}}\left(1-\frac{\sigma_{c r}}{\sigma_{c r, r}}\right)
$$

gdzie: $\eta$ - współczynnik zależny od rozkładu obciążenia i warunków podparcia płyty usztywniającej, $b_{r}$ - szerokość płyty usztywniającej, $D_{r}$ - sztywność zginania płyty usztywniającej, $\sigma_{c r}$ - naprężenia krytyczne płyty wspornikowej (,krytycz- 
nej”), $\sigma_{c r, r}$ - naprężenia krytyczne płyty usztywniającej podpartej przegubowo dla jednej półfali występującej na długości wyboczeniowej $\left(l_{c r}\right)$ płyty wspornikowej (zakłada się zgodność kątów obrotu i momentów zginających na krawędzi łączenia ścianek). Uwaga: formuła w nawiasie wzoru (3) uwzględnia w sposób przybliżony niekorzystny wpływ naprężeń ściskających w płycie usztywniającej [3].

W przypadku swobodnego podparcia ścianki wspornikowej (dla $\kappa=0$ ) przy stałym wzdłużnym rozkładzie naprężeń, na jej długości powstaje jedna półfala wyboczenia równa długości segmentu $\left(l_{c r}=l_{s}\right)$. Przy wzdłużnej zmienności naprężeń może powstać jedna lub co najwyżej dwie półfale wyboczenia o silnie zróżnicowanych amplitudach. W tym przypadku „półfala krytyczna” jest niesymetryczna (względem osi poprzecznej płyty), a jej maksymalne ugięcia występują od strony maksymalnych naprężeń (por.rys.10 dla $\kappa=0 \mathrm{w}$ pracy [8]).

W przypadku $\kappa>0$ występuje sprężyste zamocowanie płyty wspornikowej w płycie sąsiedniej, a długość wyboczeniowa „półfali krytycznej” ma z reguły wartość mniejszą od długości segmentu pręta cienkościennego $\left(l_{c r} \leq l_{s}\right)$. Długość tę można oszacować wg wzoru aproksymacyjnego (4) wyprowadzonego w pracy [8]. Dla osiowo ściskanej i sprężyście zamocowanej płyty wspornikowej przy stałej (na długości) intensywności naprężeń wzór ten ma postać:

$$
l_{c r}=b_{s}\left(\frac{2.02-0.37 \kappa}{\kappa^{0.25}}\right)
$$

W niniejszej pracy zbadano, że wzór (4) można także bezpiecznie stosować do oszacowania długości wyboczeniowej w typowych przypadkach mimośrodowego ściskania (por. rys.2).

Z uwagi na to, że dla płyty wspornikowej, w każdym przypadku zamocowania $(0 \leq \kappa \leq 1)$ długość wyboczeniowa jest większa od szerokości płyty $\left(l_{c}>b_{s}\right)$, konserwatywną ocenę sztywności obrotowej można uzyskać ze wzoru (3) przyjmując $\eta=2$ dla przekroju ściskanego, oraz $\eta=4$ dla przekroju zginanego $[3,8]$. Takie podejście upraszcza obliczenia i pozwala na bezpieczne oszacowanie naprężeń krytycznych. Wzory na naprężenia krytyczne płyty usztywniającej dla jednej półfali wyboczenia na długości $l_{c r}$ płyty podpieranej (słabszej) podano np. w pracach $[3,9]$.

Obliczenia są zatem iteracyjne, ponieważ do wyznaczenia sztywności obrotowej $C_{\theta}$ potrzebne są naprężenia krytyczne $\sigma_{c r}$ i $\sigma_{c r, r}$, które zależą m.in. od wskaźnika $\kappa$. Z kolei wskaźnik utwierdzenia $\kappa$ zależy od sztywności obrotowej $C_{\theta}$ i ostatecznie od obliczanych naprężeń krytycznych $\sigma_{c r}$. Jednakże w praktyce obliczeniowej, przy założeniu wstępnej wartości wskaźnika $\kappa$ (np. z przedziału $0.2 \div 0.4$ ) proces ten jest szybko zbieżny. Wystarczającą z technicznego punktu widzenia dokładność uzyskuje się już po $2-3$ iteracjach. Oczywiście w każdym przypadku można skorzystać z dodatkowego uproszczenia zaproponowanego w pracy [8]. Polega ono na tym, że w każdym kroku obliczeniowym za $\sigma_{c r, r}$ przyjmuje się minimalne naprężenia krytyczne ścianki podpierającej 
(tj. $\sigma_{c r, r}=4 \sigma_{E, r}$ dla ściskania przekroju lub $\sigma_{c r, r}=23.9 \sigma_{E, r}$ dla zginania przekroju W płaszczyźnie środnika, gdzie: $\sigma_{E, r}$ - naprężenia Eulera dla płyty podpierającej). W tym przypadku wystarczy zazwyczaj jedna iteracja.

\section{Funkcja ugięcia i stan naprężenia płyty wspornikowej}

Funkcję ugięcia sprężyście zamocowanej i mimośrodowo ściskanej płyty wspornikowej przy występowaniu wzdłużnej zmienności naprężeń przyjęto w postaci:

$$
w_{s}\left(x_{s}, y_{s}\right)=t_{s} \sum_{i=1}^{i_{o}}\left[f_{i 2}\left((1-\kappa) \frac{y_{s}}{b_{s}}+\kappa\left(\frac{y_{s}}{b_{s}}\right)^{2}\right)+\sum_{p=3}^{p_{o}} f_{i p}\left(\frac{y_{s}}{b_{s}}\right)^{p}\right] \sin \left(\frac{i \pi x_{s}}{l_{s}}\right)
$$

gdzie: $f_{i 2}, f_{i p}$ - bezwymiarowe, swobodne parametry funkcji ugięcia.

Zalety funkcji (5) do aproksymowania złożonej postaci wyboczenia płyt wspornikowych w złożonych stanach naprężenia omówiono w pracach $[5,7,8]$.

W przypadku analizy stateczności płyty wspornikowej stanowiącej część składową pręta cienkościennego o przekroju otwartym, w której akceptuje się hipotezę płaskich przekrojów lub hipotezę deplanacji przekroju (w zależności od sposobu obciążenia), rozkład naprężeń normalnych (por.rys.1) można przedstawić w postaci $[6,7]$ :

$$
\sigma_{x}=\sigma_{0}\left(1-\alpha_{s} \frac{y_{s}}{b_{s}}\right) \beta_{i}\left(x_{s}\right)
$$

gdzie: $\sigma_{0}$ - krawędziowe naprężenie porównawcze (dodatnie kiedy ściskające) na krawędzi zawierającej początek lokalnego układu współrzędnych $\left(y_{s}=0\right.$, por. rys.1), $\beta_{i}\left(x_{s}\right)$ - funkcja rozkładu naprężeń na długości płyty, $\alpha_{s}$ - współczynnik rozkładu naprężeń na szerokości płyty wg wzoru:

$$
\alpha_{s}=1-\sigma_{0}^{I} / \sigma_{0}
$$

W niniejszej pracy rozpatrzono następujące przypadki wzdłużnego rozkładu naprężeń: 1) rozkład stały $(m=0), 2)$ rozkład liniowy oraz, 3$)$ rozkład nieliniowy wg paraboli 2. stopnia. W przypadkach 2 i 3 funkcję $\beta_{i}\left(x_{s}\right)$ wg wzoru (6) można przedstawić odpowiednio $\mathrm{w}$ postaci:

$$
\begin{aligned}
& \beta_{1}\left(x_{s}\right)=1-m_{1} x_{s} / l_{s} \\
& \beta_{2}\left(x_{s}\right)=1-m_{2} x_{s}^{2} / l_{s}^{2}
\end{aligned}
$$


gdzie $m_{i}$ - współczynnik charakteryzujący wzdłużną zmienność naprężeń wg wzoru:

$$
m_{i}=1-\sigma_{1} / \sigma_{0}
$$

Wzdłużny rozkład naprężeń wg funkcji liniowej $(6,8)$ lub nieliniowej $(6,9)$ można uzyskać przez wprowadzenie naprężeń stycznych [12] lub wzdłużnych sił masowych (por.rys.1), o rozkładzie dobranym w zależności od sposobu obciążenia pręta cienkościennego. Sposób zastąpienia naprężeń stycznych odpowiednim rozkładem sił masowych w płytach wspornikowych opisano w pracy [5]. Wprowadzenie wzdłużnych sił masowych oraz opis rozkładu naprężeń normalnych wg wzoru (6) upraszcza funkcję ugięcia (5) poprzez redukcję liczby swobodnych parametrów niezbędnych do aproksymacji postaci wyboczenia. Pozwala to na analizę stateczności płyty wspornikowej (ścianki przekroju) w tych przypadkach, w których rozkład i intensywność naprężeń stycznych nie wpływa istotnie na postać utraty stateczności $[5,7]$. W niniejszej pracy pominięto wpływ naprężeń stycznych, przyjmując wzdłużny rozkład naprężeń normalnych wg wzoru (6).

\section{Naprężenie krytyczne}

Naprężenie krytyczne $\left(\sigma_{c r}\right)$ lokalnej utraty stateczności mimośrodowo ściskanej płyty wspornikowej przy wzdłużnej zmienności naprężeń odniesiono do najbardziej ściskanej krawędzi (por.rys. 2 - linia gruba) i wyrażono w postaci wzoru:

$$
\sigma_{c r}=k \sigma_{E}
$$

gdzie $\sigma_{E}$ - naprężenia Eulera dla płyty wg [1,9].

Płytowe współczynniki wyboczeniowe $(k)$ wyznaczono metodą energetyczną. Całkowita energia potencjalna układu wynosi:

$$
U_{s}=V_{s, 1}+V_{s, 2}-L_{s}
$$

gdzie: $V_{s, 1}$ - energia sprężysta zginania płyty, $V_{s, 2}$ - energia sprężystego zamocowania krawędzi podłużnej $\left(y_{s}=0\right), L_{s}$ - praca sił zewnętrznych.

Ponieważ funkcję ugięcia płyty zapisano szeregiem sinusowo - wielomianowym postaci (5), energię sprężystą $\left(V_{s, 1}\right)$ wyznaczono w sposób zaproponowany w pracy [2], a funkcję pracy sił zewnętrznych $\left(L_{s}\right)$ wyznaczono z sekwencji wzorów wyprowadzonych w pracy [5]. Natomiast energię sprężystego zamocowania $\left(V_{s, 2}\right)$ krawędzi podłużnej wyznaczono wg [1] ze wzoru: 


$$
V_{s, 2}=\frac{C_{\theta}}{2} \int_{0}^{l_{s}}\left[\left(\frac{\partial w_{s}}{\partial y_{s}}\right)_{y_{s}=0}^{2}\right] d x
$$

Naprężenia krytyczne obliczono z układu równań:

$$
\partial U_{s} / \partial f_{i p}=0
$$

sprowadzając zagadnienie do problemu wyznaczania wartości i wektorów własnych.

Obliczenia współczynników wyboczeniowych $k$ wykonano programem komputerowym Ncr_plyta_sw-spręż-(3).nb (opracowanym w środowisku pakietu Mathematica $^{\circledR}$ [11]) i rozbudowanym w stosunku do aplikacji opisanej w pracy [6] o kolejne moduły obliczeniowe. Program umożliwia m.in. tablicowanie współczynników, wyznaczanie wzorów aproksymacyjnych oraz graficzną prezentację wyników obliczeń (wykresy, postacie wyboczenia itp.). Funkcję ugięcia płyty aproksymowano szeregiem (5), przy narzuceniu wartości początkowych wskaźnika utwierdzenia wg wzoru (2) od $\kappa=0$ dla krawędzi swobodnie podpartej do $k=1$ dla krawędzi utwierdzonej. Parametr $i_{o}$ określający ilość ,półfal” funkcji sinus w kierunku osi $x_{s}$ szeregu (5) dobierano w zależności od stosunku wymiarów płyty $\left(\gamma_{s}=l_{s}\left(b_{s}\right)\right.$, rozkładu naprężeń działających w jej płaszczyźnie oraz wskaźnika $\kappa$. Na podstawie analizy zbieżności wyników (analogicznej do przedstawionej w pracy [5]), do obliczeń współczynników $k$ sprężyście zamocowanych płyt wspornikowych o $\gamma_{s} \leq 8$ oraz wartości parametrów: $0 \leq m \leq 1$ oraz $0 \leq \kappa \leq 1$ przyjęto $\mathrm{w}$ praktyce $i_{o}=8$. Dało to wystarczającą dokładność z technicznego punktu widzenia przy jednoczesnej redukcji ilości obliczeń. $\mathrm{W}$ tabeli 1 podano przyporządkowanie numeru krzywej na poszczególnych wykresach (rys. $3 \div 8$ ) do współczynnika $\varepsilon$ oraz wskaźnika $\kappa$ wg wzorów $(1,2)$.

Tabela 1. Przyporządkowanie numeru krzywej na rys. 3-8 do współczynnika $\varepsilon$ oraz wskaźnika $\kappa$ Table 1. Assignment of the curve numbers in Figs 3-8 to the coefficient $\varepsilon$ and index $\kappa$

\begin{tabular}{|c|c|c|c|c|c|c|c|c|c|c|c|}
\hline $\mathrm{Nr}$ & $\mathbf{1}$ & $\mathbf{2}$ & $\mathbf{3}$ & $\mathbf{4}$ & $\mathbf{5}$ & $\mathbf{6}$ & $\mathbf{7}$ & $\mathbf{8}$ & $\mathbf{9}$ & $\mathbf{1 0}$ & $\mathbf{1 1}$ \\
\hline $\boldsymbol{\varepsilon}$ & 0 & 0,15 & 0,3 & 0,6 & 1 & 2 & 3 & 5 & 10 & 20 & $10^{4}$ \\
\hline $\boldsymbol{\kappa}$ & 0 & 0,07 & 0,13 & 0,231 & 0,333 & 0,5 & 0,6 & 0,714 & 0,83 & 0,909 & 1 \\
\hline
\end{tabular}

\section{Wykresy współczynnika wyboczeniowego $\boldsymbol{k}$}

Na rysunkach 3 do 5 pokazano wykresy współczynnika $k$ dla $\alpha_{s}=3$ (rys.3), $\alpha_{s}=-1$ (rys.4) i $\alpha_{s}=0.5$ (rys.5) przy liniowym $\left(m_{1}=1\right)$, w kierunku podhużnym, rozkładzie naprężeń $\left(\sigma_{x} \mathrm{wg}(6,8)\right) \mathrm{w}$ funkcji $\gamma_{s}$ oraz $\varepsilon$ i $\kappa$ wg tabeli 1 . Odpowiednie rozkłady naprężeń pokazano na rys. 2 . 


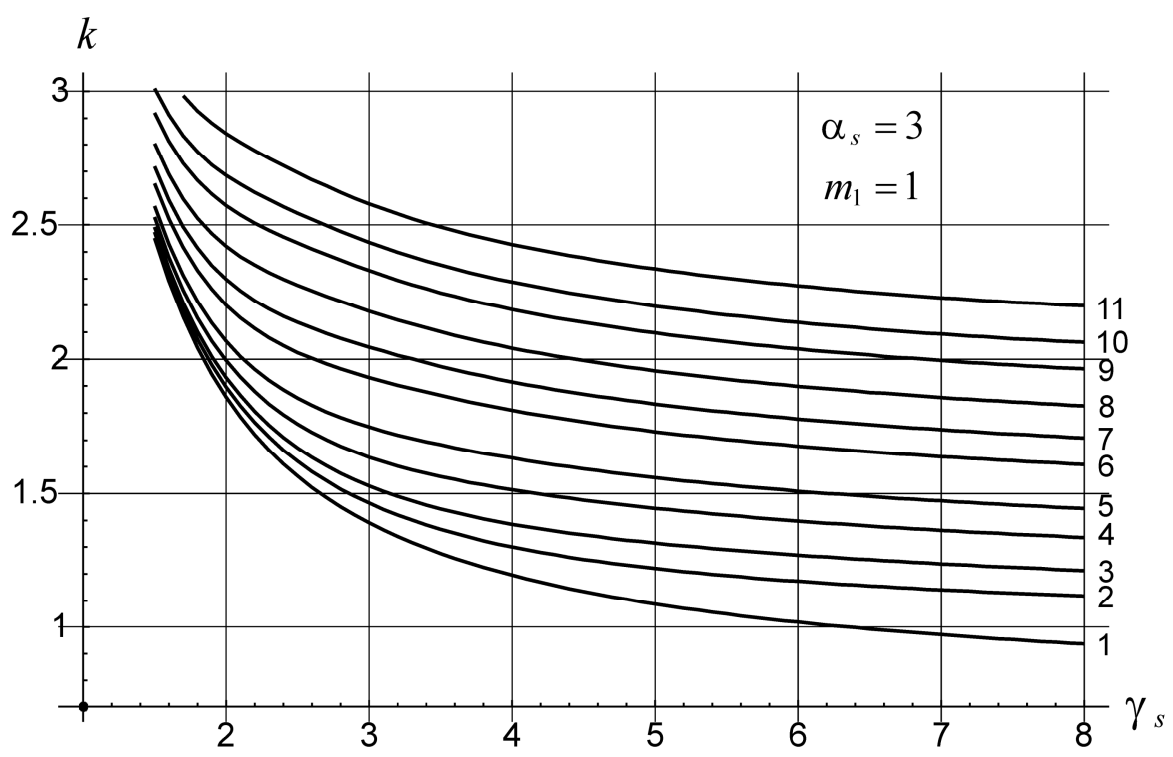

Rys. 3. Wykresy współczynnika $k$ dla $\alpha_{s}=3$ i $m_{1}=1$ oraz $\varepsilon$ i $\kappa$ wg tabeli 1

Fig. 3. The plots of the coefficient $k$ for $\alpha_{s}=3$ and $m_{1}=1$, and also $\varepsilon$ and $\kappa$ in acc. with Table 1

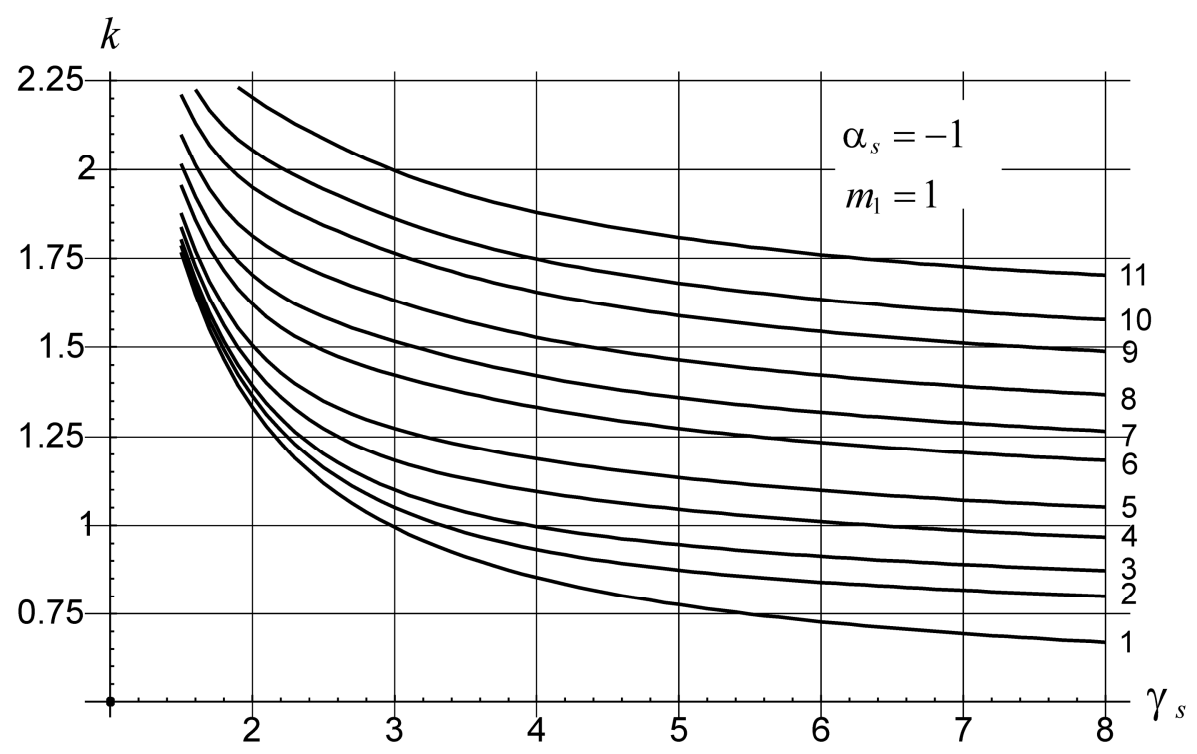

Rys. 4. Wykresy współczynnika $k$ dla $\alpha_{s}=-1$ i $m_{1}=1$ oraz $\varepsilon$ i $\kappa$ wg tabeli 1

Fig. 4. The plots of the coefficient $k$ for $\alpha_{s}=-1$ and $m_{1}=1$, and also $\varepsilon$ and $\kappa$ in acc. with Table 1 


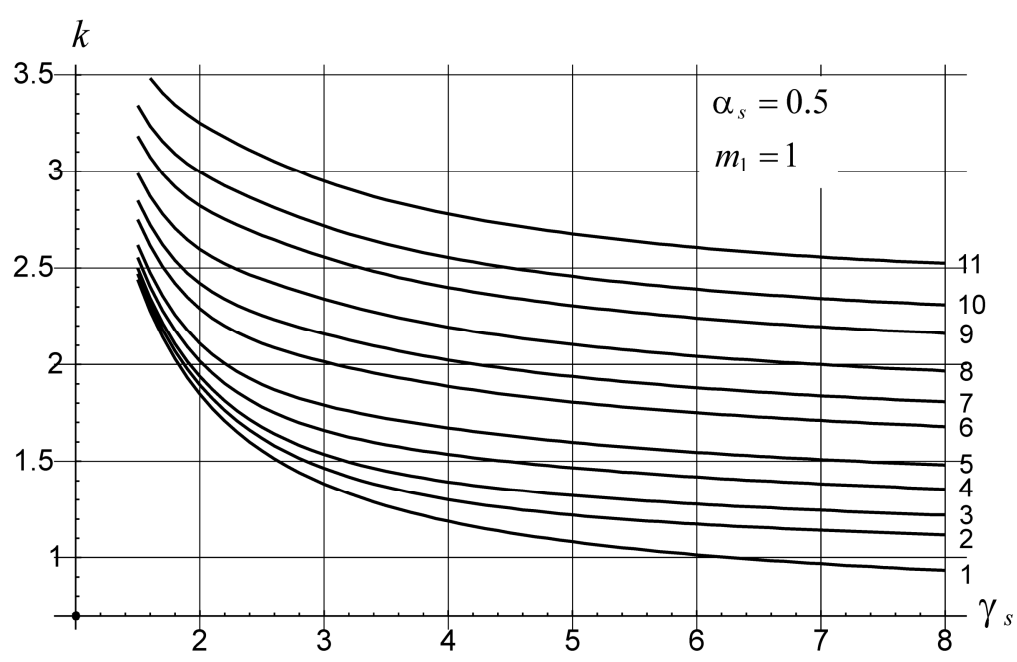

Rys. 5. Wykresy współczynnika $k$ dla $\alpha_{s}=0.5$ i $m_{1}=1$ oraz $\varepsilon$ i $\kappa$ wg tabeli 1

Fig. 5. The plots of the coefficient $k$ for $\alpha_{s}=0.5$ and $m_{1}=1$, and also $\varepsilon$ and $\kappa$ in acc. with Table 1

Na rysunkach 6 do 8 pokazano wykresy współczynnika $k$ dla $\alpha_{s}=2$ (rys.6), $\alpha_{s}=10^{4}$ (rys.7) i $\alpha_{s}=1$ (rys.8) przy nieliniowym $\left(m_{2}=1\right)$, w kierunku podłużnym, rozkładzie naprężeń $\left(\sigma_{x} \mathrm{wg}(6,9)\right) \mathrm{w}$ funkcji $\gamma_{s}$ oraz $\varepsilon$ i $\kappa$ wg tabeli 1 . Rozkłady naprężeń pokazano jak poprzednio na rys.2.

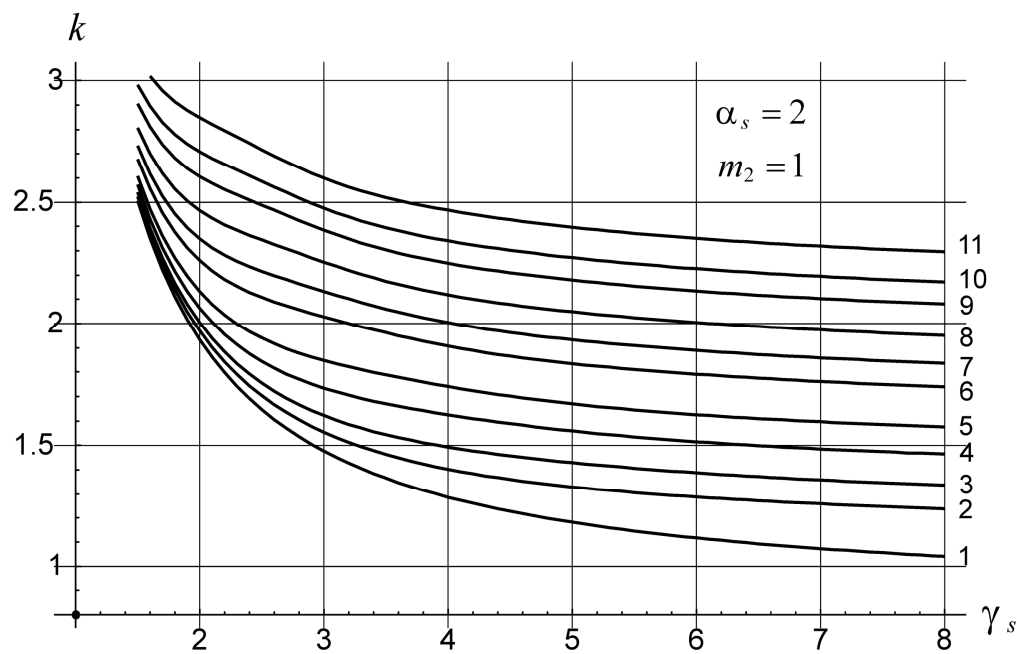

Rys. 6. Wykresy współczynnika $k$ dla $\alpha_{s}=2$ i $m_{2}=1$ oraz $\varepsilon$ i $\kappa$ wg tabeli 1

Fig. 6. The plots of the coefficient $k$ for $\alpha_{s}=2$ and $m_{2}=1$, and also $\varepsilon$ and $\kappa$ in acc. with Table 1 


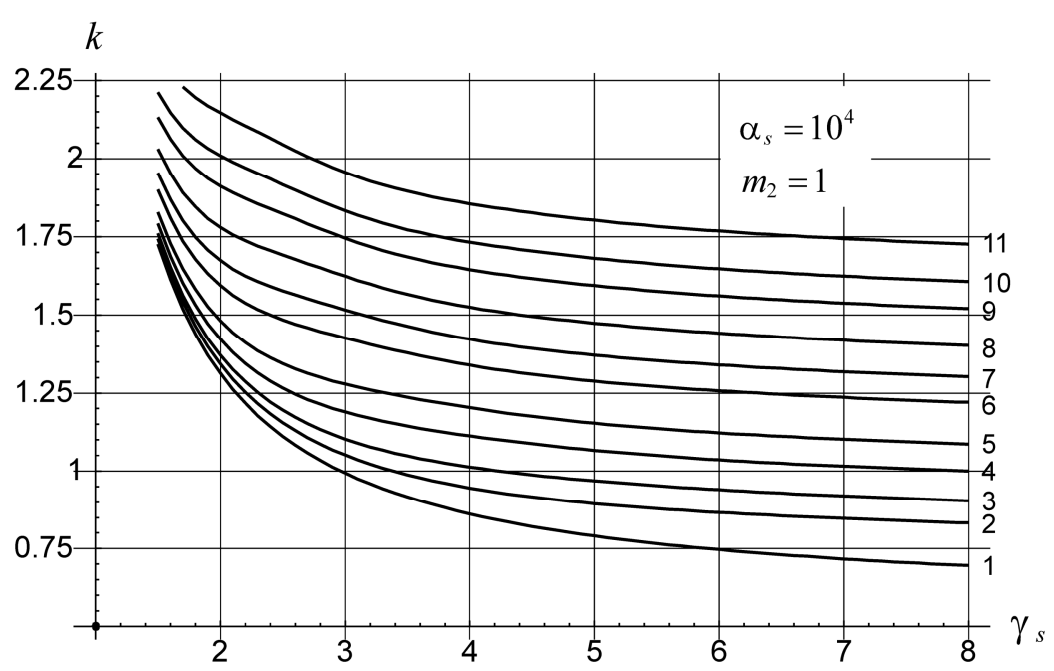

Rys. 7. Wykresy współczynnika $k$ dla $\alpha_{s}=10^{4}$ i $m_{2}=1$ oraz $\varepsilon$ i $\kappa$ wg tabeli 1

Fig. 7. The plots of the coefficient $k$ for $\alpha_{s}=10^{4}$ and $m_{2}=1$, and also $\varepsilon$ and $\kappa$ in acc. with Table 1

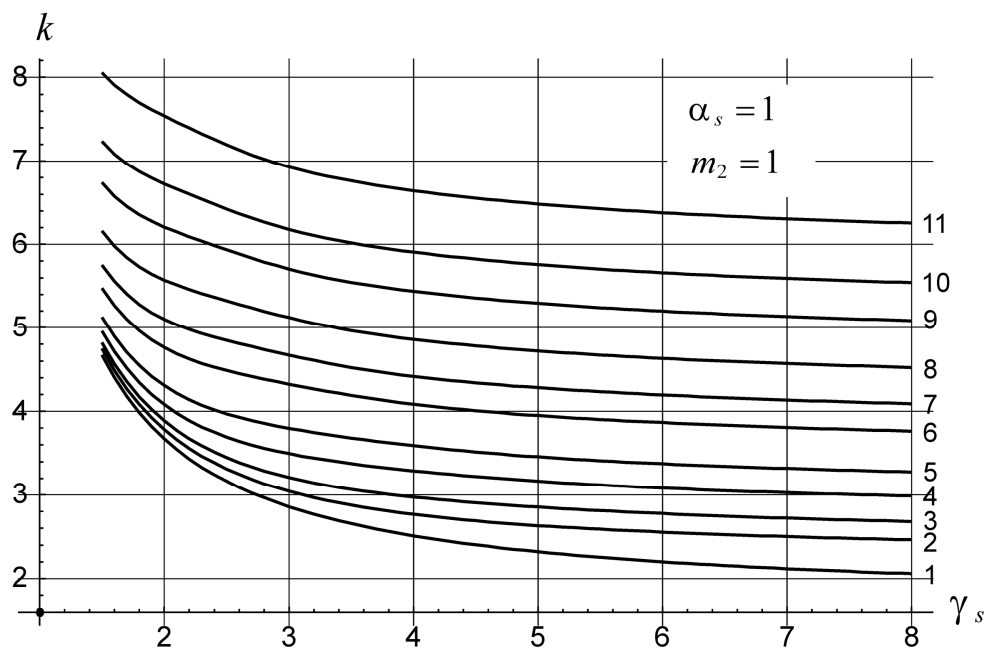

Rys. 8. Wykresy współczynnika $k$ dla $\alpha_{s}=1$ i $m_{2}=1$ oraz $\varepsilon$ i $\kappa$ wg tabeli 1

Fig. 8. The plots of the coefficient $k$ for $\alpha_{s}=1$ and $m_{2}=1$, and also $\varepsilon$ and $\kappa$ in acc. with Table 1

$\mathrm{Na}$ rysunku 9. porównano współczynniki $k$ dla sprężyście zamocowanej $(\varepsilon=3, \kappa=0.6)$ płyty wspornikowej przy $\alpha_{s}=-1$ oraz liniowym rozkładzie naprężeń w kierunku podłużnym $\left(\sigma_{x} \mathrm{wg}(6,8)\right)$ dla $m_{1}=0 ; 0.25 ; 0.5 ; 0.75 \mathrm{i} 1 \mathrm{w}$ funkcji $\gamma_{s}$. Wraz ze wzrostem wartości parametru $m_{1}$ naprężenia krytyczne rosną i zanika girlandowy charakter krzywych charakterystyczny dla $m_{i}=0$. 


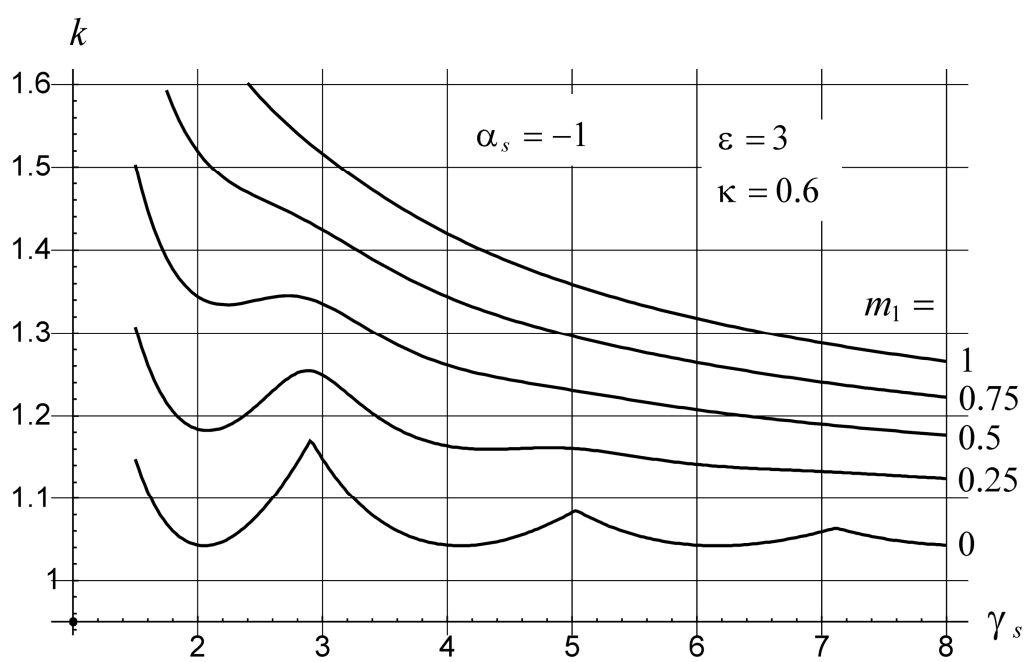

Rys. 9. Porównanie wykresów współczynnika $k$ dla $\alpha_{s}=-1$, sprężyście zamocowanej $(\varepsilon=3, \kappa=0.6)$ płyty wspornikowej przy liniowym rozkładzie naprężeń dla $m_{1}=0 ; 0.25 ; 0.5 ; 0.75$ i 1

Fig. 9. Comparison of the coefficient $k$ plots for $\alpha_{s}=-1$, for the elastically restrained $(\varepsilon=3, \kappa=0.6)$ cantilever plate, assuming non-linear stress distribution, for $m_{1}=0 ; 0.25 ; 0.5 ; 0.75$; and 1

Z porównania wykresów pokazanych na rys.9. wynika ponadto, że dla pośrednich wartości parametru $m_{1}$ wartość współczynnika $k$ można konserwatywnie oszacować w oparciu o interpolację liniową, np. $k^{m=0.75} \approx\left(k^{m=1}+k^{m=0.5}\right) / 2$; $k^{m=0.5} \approx\left(k^{m=1}+k^{m=0}\right) / 2$ itd.

$Z$ kolei na rys.10. porównano współczynniki $k$ dla sprężyście zamocowanej $(\varepsilon=1, \kappa=0.333)$ płyty wspornikowej przy $\alpha_{s}=10^{4}$ oraz nieliniowym rozkładzie naprężeń w kierunku podłużnym $\left(\sigma_{x} \mathrm{wg}(6,9)\right)$ dla parametru $m_{2}=0 ; 0.25 ; 0.5$; 0.75 i $1 \mathrm{w}$ funkcji $\gamma_{s}$.

Również w tym przypadku, wraz ze wzrostem parametru $m_{2}$ naprężenia krytyczne rosną. Ponadto z analogicznego (jak dla rozkładu liniowego) porównania wykresów wynika, że dla pośrednich wartości parametru $m_{2}$ wartość współczynnika $k$ można konserwatywnie oszacować w oparciu o interpolację liniową, chociaż w tym przypadku błędy takiego oszacowania będą większe (ale na korzyść bezpieczeństwa).

W celu umożliwienia oszacowania współczynnika $k$ dla wzdłużnego liniowego lub nieliniowego rozkładu naprężeń i pośrednich wartości parametru $m_{i}$ z przedziału $0<m_{i}<1$ (np. na podstawie wykresów współczynników $k$ dla $m_{i}=1$ ), w rozdziale 6 niniejszej pracy podano wzory aproksymacyjne współczynnika $k$ dla mimośrodowo ściskanej płyty wspornikowej ( $\alpha_{s}$ wg rys.2.) przy stałym rozkładzie naprężeń na jej długości $\left(m_{i}=0\right)$. Uwaga: dodatkowe wykresy współczynników $k$ dla innych wartości parametrów $\alpha_{s}$ i $m_{i}$ zamieszczono w pracy [6]. 


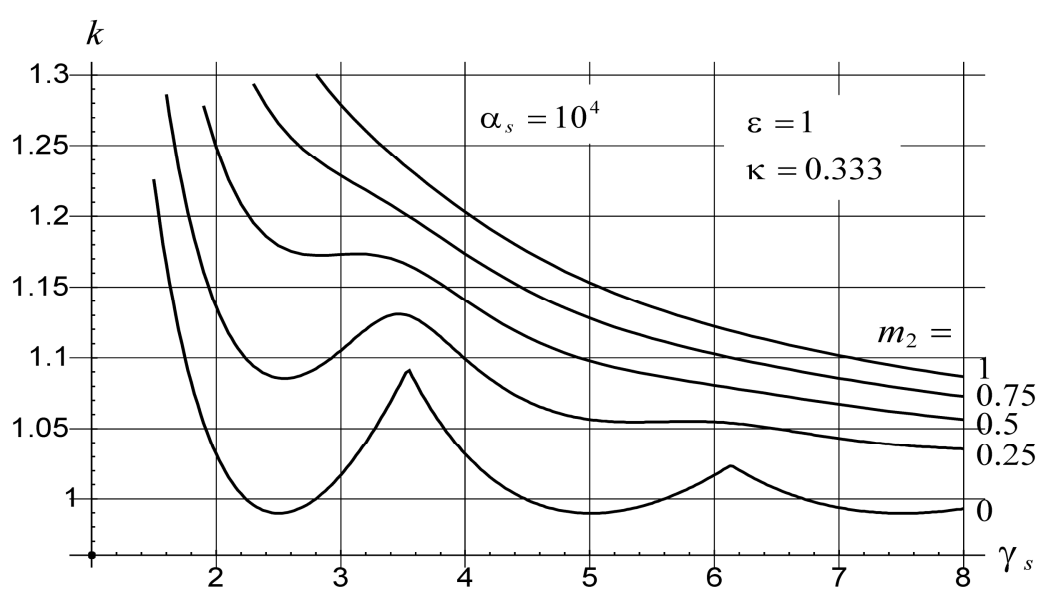

Rys. 10. Porównanie wykresów współczynnika $k$ dla $\alpha_{s}=10^{4}$, sprężyście zamocowanej $(\varepsilon=1, \kappa=0.33)$ płyty wspornikowej przy nieliniowym rozkładzie naprężeń, $m_{2}=0 ; 0.25 ; 0.5 ; 0.75$ i 1

Fig. 10. Comparison of the coefficient $k$ plots for $\alpha_{s}=10^{4}$, for the elastically restrained $(\varepsilon=1, \kappa=0.33)$ cantilever plate, assuming non-linear stress distribution, for $m_{2}=0 ; 0.25 ; 0.5 ; 0.75$; and 1

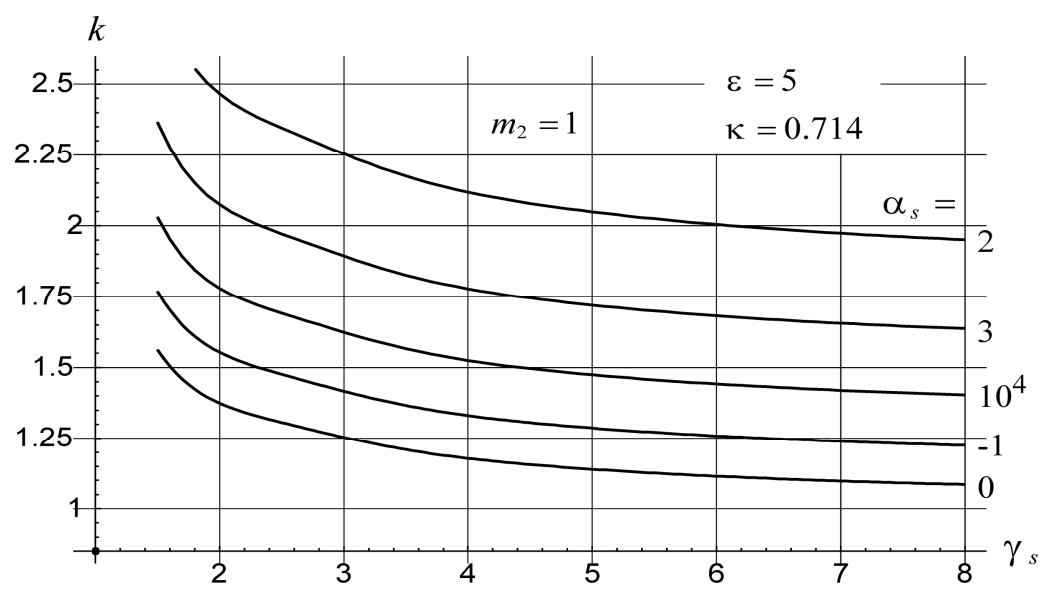

Rys. 11. Porównanie wykresów współczynnika $k$ dla sprężyście zamocowanej $(\varepsilon=5, \kappa=0.714)$ płyty wspornikowej przy nieliniowym rozkładzie naprężeń $\left(m_{2}=1\right)$ dla różnych wartości $\alpha_{s}$

Fig. 11. Comparison of the coefficient $k$ plots for the elastically restrained $(\varepsilon=5, \kappa=0.714)$ cantilever plate, assuming non-linear stress distribution $\left(m_{2}=1\right)$ and different values of $\alpha_{s}$

Na rysunku 11. porównano współczynniki $k$ dla sprężyście zamocowanej $(\varepsilon=5, \kappa=0.714)$ płyty wspornikowej przy nieliniowym rozkładzie naprężeń w kierunku podłużnym $\left(m_{2}=1\right)$ oraz różnych (liniowych) rozkładach w kierunku poprzecznym $\left(\alpha_{s}=0 ;-1 ; 10^{4} ; 3 ; 2\right) \mathrm{w}$ funkcji $\gamma_{s}$. W tym przypadku, wraz ze zmniejszaniem się strefy naprężeń ściskających (w stosunku do przypadku $\alpha_{s}=0$ ) naprężenia krytyczne rosną. 


\section{Przypadek stałego rozkładu naprężeń na długości płyty}

W przypadku stałego rozkładu naprężeń $\left(m_{i}=0\right)$ wykresy współczynników wyboczeniowych mają postać krzywych girlandowych (por.rys.9 i rys.10). Dla płyt, których długość jest wielokrotnością $l_{c r}$ wg (4) otrzymuje się $k=k_{\min }$. Stąd dla długich płyt (ścianek przekroju) współczynnik wyboczeniowy szybko dąży do wartości minimalnej $\left(k_{\infty}=k_{\min }\right)$. W praktyce projektowej przyjmuje się $\mathrm{z}$ reguły wartość minimalną $k_{\min }$ dla danego schematu statycznego i sposobu obciążenia płyty, (np. $k=0.43$ dla swobodnie podpartej i równomiernie ściskanej płyty wspornikowej lub $k=4$ dla tak samo obciążonej płyty przęsłowej [15]).

$\mathrm{W}$ niniejszej pracy na podstawie obliczeń wykonanych programem $\mathrm{Ncr}$ plyta_sw-spręż-(3).nb, wyznaczono wartości współczynników $k_{\min }\left(\right.$ dla $\left.m_{i}=0\right) \overline{\mathrm{i}}$ wyprowadzono formuły aproksymacyjne dla przypadków mimośrodowego ściskania (por.rys.2.) w funkcji wskaźnika $\kappa$. Wzory wyprowadzono przy założeniu rozbicia ich ważności na dwa przedziały zmienności wskaźnika $\kappa \mathrm{i} \mathrm{w}$ takiej formie zamieszczono w tabeli 2 . W kolumnie 1 podano wartości parametru $\alpha_{s}$ wg wzoru (7), (por.rys.2), w kol. 2 - współczynniki $k$ dla przypadku $\kappa=0$, w kol. 4 - współczynniki $k$ dla przypadku $\kappa=0.05$, a w kol. 5 wzór aproksymacyjny współczynnika $k \mathrm{w}$ funkcji $\kappa \mathrm{W}$ przedziale $0.05 \leq \kappa \leq 1$. Natomiast w przedziale $0 \leq \kappa \leq 0.05$ można stosować interpolację liniową.

Tabela 2. Współczynniki wyboczeniowe $k_{\min }$ dla $\alpha_{s}$ wg rys.2. przy $m_{i}=0$

Table 2. Buckling coefficients $k_{\min }$ for $\alpha_{s}$ according to Fig.2. by $m_{i}=0$

$\begin{array}{ccccc}\boldsymbol{\alpha}_{\boldsymbol{s}} & \boldsymbol{\kappa}=\mathbf{0} & \mathbf{0}<\boldsymbol{\kappa}<\mathbf{0 . 0 5} & \boldsymbol{\kappa}=\mathbf{0 . 0 5} & \mathbf{0 . 0 5}<\boldsymbol{\kappa}<\mathbf{1} \\ 1 & 2 & 3 & 4 & 5 \\ \mathbf{0} & 0.425 & & 0.537 & 0.49+0.974 \kappa-0.822 \kappa^{2}+0.632 \kappa^{3} \\ \mathbf{2} & 0.851 & & 1.069 & 0.986+1.727 \kappa-1.494 \kappa^{2}+0.914 \kappa^{3} \\ \mathbf{1 0} & 0.567 & & 0.712 & 0.652+1.258 \kappa-1.051 \kappa^{2}+0.741 \kappa^{3} \\ \mathbf{- 1} & 0.486 & \text { Interpolacja } & 0.609 & 0.556+1.104 \kappa-0.931 \kappa^{2}+0.688 \kappa^{3} \\ \mathbf{3} & 0.681 & \text { liniowa } & 0.856 & 0.786+1.46 \kappa-1.225 \kappa^{2}+0.811 \kappa^{3} \\ \mathbf{1} & 1.702 & & 2.123 & 1.917+4.336 \kappa-4.605 \kappa^{2}+4.2 \kappa^{3} \\ \mathbf{0 . 5} & 0.681 & & 0.856 & 0.78+1.59 \kappa-1.375 \kappa^{2}+1.111 \kappa^{3}\end{array}$

Dla porównania, w pierwszym wierszu tabeli 2. podano przypadek równomiernie ściskanej płyty wspornikowej. Uwaga: bardziej rozbudowaną postać wzoru dla $\alpha_{s}=0$, ale obowiązującą już w całym przedziale $0 \leq \kappa \leq 1$ podano w pracy [8]. 


\section{Oszacowanie współczynnika $\boldsymbol{k}$ przy wzdłużnej zmienności naprężeń dla $\gamma_{s}=\mathbf{8} \div \mathbf{5 0}$}

Na rysunkach 3 do 11 pokazano wykresy współczynników $k$ w przedziale $\gamma_{s}=1.5 \div 8$. Na podstawie obliczeń wykonanych programem Ncr_plyta_sw-spręż(3). $n b$ oraz testów wykonanych wzorami aproksymacyjnymi wyprowadzonymi w pracy [8] dla $\alpha_{s}=0$ stwierdzono, że w przedziale $\gamma_{s}=8 \div 50$ współczynnik $k_{p}$ można oszacować z następującej formuły przybliżonej:

$$
k_{\gamma}=k_{\min }+\frac{\left(k_{8}-k_{\min }\right)}{1764}\left(\gamma_{s}^{2}-100 \gamma_{s}+2500\right)
$$

gdzie: $k_{\min }$ - współczynnik obliczony dla danego schematu obciążenia i wartości wskaźnika $\kappa$ wg tabeli $2, k_{8}$ - współczynnik dla $\gamma_{s}=8$ odczytany z odpowiedniego wykresu (rys. 3 do 11 lub z wykresów zamieszczonych w pracy [6]).

Maksymalne różnice współczynnika $k_{\gamma}$ oszacowanego wg wzoru (15) $\mathrm{w}$ stosunku do wartości wyznaczonych $\mathrm{w} / \mathrm{w}$ programem nie przekroczyły $+2.5 \%$ w przedziale $10<\gamma_{s}<20$ oraz $-5 \% \mathrm{w}$ przedziale $40<\gamma_{s}<50$. Oczywiście przy założeniu możliwie dokładnego odczytania wartości $k_{8} \mathrm{z}$ odpowiedniego wykresu.

W przypadku płyt długich $\gamma_{s}>50$ wpływ wzdłużnej zmienności naprężeń na wartość współczynnika $k$ jest niewielki (poniżej 5\%) i z technicznego punktu widzenia można w tym przedziale przyjmować $k=k_{\min }$ wg tabeli 2 .

\section{Przykład obliczeniowy}

Zastosowanie pokazanych w pracy wykresów oraz wyprowadzonych wzorów aproksymacyjnych (tabela 2, wzór (15)) pokazano na przykładzie.

Przykład. Dana jest płyta wspornikowa (ścianka przekroju cienkościennego) o wymiarach i rozkładzie naprężeń wg rys.12. Wyznaczyć naprężenie krytyczne przy liniowym, na długości płyty, rozkładzie naprężeń dla $m_{1}=1$.

Dane: $\kappa=0.333 ; \gamma_{s}=1400 / 100=14 ; E=210 \mathrm{GPa} ; v=0.3$;

Naprężenia Eulera dla płyty [15]: $\sigma_{E}=190000 *(3 / 100)^{2}=171 \mathrm{MPa}$, współczynnik poprzecznego rozkładu naprężeń: $\alpha_{s}=1-(120 /(-60))=3$. Ponieważ dla $\gamma_{s}=14$ nie dysponujemy wykresem współczynnika $k$, stad do jego oszacowania wykorzystamy formułę (15), (oczywiście wartość ,ścisłą" $k$ możemy wyznaczyć programem Ncr_ptyta_sw-spręż-(3).nb, przy zwiększeniu wartości parametru $i_{o}$ ). 


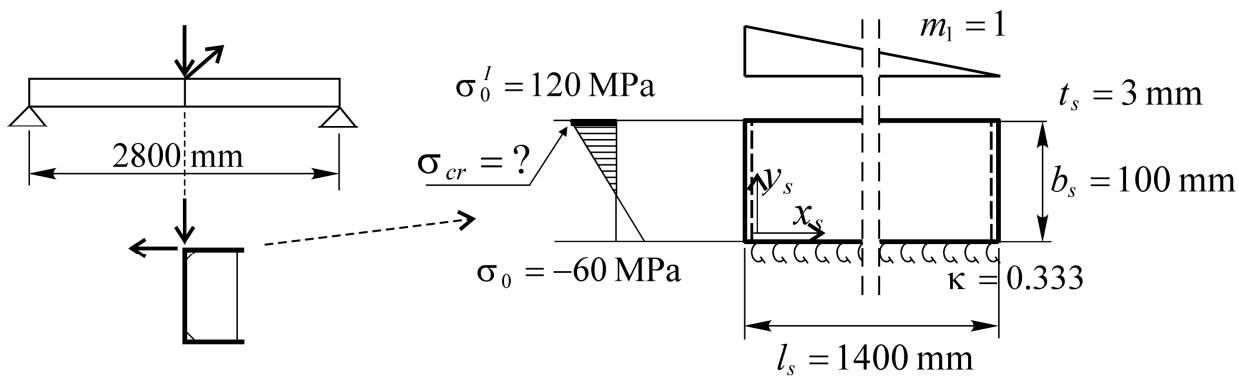

Rys. 12. Schemat statyczny ścianki (płyty)

Fig. 12. The static scheme of the thin-wall (plate)

$\mathrm{Z}$ tabeli 2 . dla $\alpha_{s}=3$ i $\kappa=0.333$ obliczono współczynnik:

$k_{\min }=0.786+1.46 * 0.333-1.225 * 0.333^{2}+0.811 * 0.333^{3}=1.17$;

Następnie z rys.3. $\left(\alpha_{s}=3\right.$, krzywa 5 , por. tabela 1 .) dla $\gamma_{s}=8$ odczytano $k_{8} \approx 1.4$;

stąd ze wzoru (15) otrzymano:

$k_{14}=1.17+(1.4-1.17) *\left(14^{2}-100 * 14+2500\right) / 1764 \approx 1.34$ (wartość ,ścisła” wyznaczona programem dla $i_{o}=20$ wyniosła $k=1.35$ ).

Dla porównania, współczynnik wyboczeniowy wyznaczony wg normy [15]

(tabl. 4.2, $\psi=-0.5$ ) przy pominięciu warunków sprężystego zamocowania oraz wzdłużnej zmienności naprężeń wyniósł $k^{E C 3}=0.69$;

Krawędziowe naprężenie krytyczne wyniosło: $\sigma_{c r}=1.34 * 171=229$ MPa i jest większe od naprężenia wyznaczonego wg [15]: $\sigma_{c r}=0.69 * 171=118 \mathrm{MPa}$ o $94 \%$.

\section{Podsumowanie}

Uwzględnienie sprężystego zamocowania krawędzi płyty (ścianki) wspornikowej w segmencie pręta cienkościennego oraz poprzecznej i wzdłużnej zmienności naprężeń prowadzi do precyzyjniejszego wyznaczenia naprężeń krytycznych wyboczenia lokalnego. Poprawia to dokładność odwzorowania zachowania się elementu cienkościennego w inżynierskim modelu obliczeniowym, co jest naturalnym kierunkiem rozwoju współczesnych metod projektowania. Pozwala to także na lepszą ocenę dokrytycznego zakresu pracy przekroju cienkościennego [7], w którym ważna jest teoria Własowa [10], oraz dokładniejsze wyznaczenie szerokości współpracujących różnie obciążonych ścianek wspornikowych.

Funkcja ugięcia postaci szeregu wielomianowo - sinusowego (5) umożliwia aproksymację postaci wyboczenia mimośrodowo ściskanej płyty wspornikowej przy wzdłużnej zmienności naprężeń oraz modelowanie warunków brzegowych jej sprężystego zamocowania przeciw obrotowi.

W przypadku wzdłużnej zmienności naprężeń $\left(m_{i}>0\right)$ wykresy współczynnika $k$ nie maja charakteru krzywych girlandowych $\mathrm{i}$ ich zbieżność do $k_{\min }$ jest znacznie wolniejsza niż w przypadku $m_{i}=0$, co może być wykorzystane 
w modelu obliczeniowym. Ze wzrostem wartości współczynnika $\varepsilon$ wg wzoru (1) oraz wskaźnika $\kappa$ wg wzoru (2) oraz wzrostem wartości parametru $m_{i}$ wg (10) rosną współczynniki naprężeń krytycznych płyt (ścianek) wspornikowych. Mniejsze współczynniki $k$ przy tych samych wartościach parametrów $k, \alpha_{s}, m_{\mathrm{i}}$ oraz $\gamma_{s}$ uzyskano dla nieliniowego rozkładu naprężeń (np. por.rys.3. krzywa 8 $\mathrm{z}$ rys. 11 . dla $\alpha_{s}=3$ ).

Wyprowadzone $\mathrm{w}$ pracy wzory aproksymacyjne zamieszczone $\mathrm{w}$ tabeli 2 oraz wykresy współczynników $k$ dla $m_{i}=1$ umożliwiają oszacowanie naprężeń krytycznych dla wartości pośrednich $0<m_{i}<1$ na podstawie interpolacji liniowej. Uzyskane $\mathrm{w}$ ten sposób wartości są mniejsze od wyliczonych programem Ncr_plyta_sw-spręż-(3).nb. W przypadku płyt długich (ścianek nie użebrowanych elementów cienkościennych) współczynnik $k$ można oszacować ze wzoru (15). Ze znaczącym wzrostem długości płyty (np. $\gamma_{s}>50$ ) maleje wpływ wzdłużnej zmienności naprężeń. W takim przypadku współczynnik $k$ można oszacować wg tabeli 2 w zależności od poprzecznego rozkładu naprężeń.

\section{Literatura}

[1] Bulson P.S. The Stability of Flat Plates. Chatto and Windus. London 1970.

[2] Jakubowski S. Macierzowa analiza stateczności i drgań własnych ścian dźwigarów cienkościennych. Archiwum Budowy Maszyn (1986), Tom XXXIII, Z.4, 357-375.

[3] Li L-y., Chen J-k. An analytical model for analyzing distortional buckling of coldformed steel sections. Thin-Walled Structures 46 (2008) 1430-1436.

[4] Rykaluk K. Pozostające naprężenia spawalnicze w wybranych stanach granicznych nośności. Prace Naukowe Instytutu Budownictwa Politechniki Wrocławskiej, 29, seria: Monografie 11, Wrocław 1981.

[5] Szychowski A. The stability of eccentrically compressed thin plates with a longitudinal free edge and with stress variation in the longitudinal direction. Thin-Walled Structures 2008, 46(5): 494-505.

[6] Szychowski A. Lokalne wyboczenie ścianki wspornikowej elementu cienkościennego przy wzdłużnej i poprzecznej zmienności naprężeń”, Materiały 59 Konferencji Naukowej KILiW PAN i KN PZITB, Lublin - Krynica 2013 (wysłano do czasopisma Budownictwo i Architektura).

[7] Szychowski A. A theoretical analysis of the local buckling in thin-walled bars with open cross-section subjected to warping torsion, Thin-Walled Structures 76 (2014) 42-55.

[8] Szychowski A. Stability of cantilever walls of steel thin-walled bars with open cross-section. Thin-Walled Structures 94 (2015): 348-358.

[9] Timoshenko S.P., Gere J.M. Theory of Elastic Stability. Part II. McGraw-Hill, New York, N.Y. 1961.

[10] Vlasow V.Z. Thin-Walled Elastic Beams. Israel Program for Scientific Translations, Jerusalem, 1961.

[11] Wolfram S. Mathematica. Cambridge University Press. 
[12] Yu C., Schafer BW. Effect of longitudinal stress gradients on elastic buckling of thin plates. J Eng Mech ASCE 2007;133(4);452-63.

[13] PN-EN 1993-1-1. Eurokod 3. Projektowanie konstrukcji stalowych. Część 1-1: Reguły ogólne i reguły dla budynków.

[14] PN-EN 1993-1-3. Eurokod 3. Projektowanie konstrukcji stalowych. Część 1-3: Reguły uzupełniające dla konstrukcji z kształtowników i blach profilowanych na zimno.

[15] PN-EN 1993-1-5. Eurokod 3. Projektowanie konstrukcji stalowych. Część 1-5: Blachownice.

\title{
STABILITY OF ECCENTRICALLY COMPRESSED CANTILEVER WALL OF A THIN-WALLED MEMBER
}

\begin{abstract}
S u m m a r y
The paper presents the results of investigations into the stability of eccentrically compressed cantilever walls constituting components of thin-walled members. The characteristics of such walls include high slenderness and susceptibility to local stability loss. To solve the problem, a model of a thin cantilever plate was used. The deflection function was written in the form of the polynomial-sine series. The conditions of elastic restraint against rotation and different stress distributions (in accordance with a constant function, linear function and the parabola $2^{0}$ ) over the length of the member were accounted for. The critical stress was referred to the edge that was most compressed for a given load case. The buckling coefficients $k$ were determined using the energy method. The plots of the coefficient $k$ were presented for those load schemes that were not found in the literature. Approximation formulas for the coefficient $k$ were derived for stress distribution that was constant over the plate length. In the formulas, different cases of eccentric compression were accounted for in the form of a function of the elastic fixity index. The means of estimating the coefficient $k$ for intermediate parameter values were discussed. Also, a simple approximation formula for long cantilever plates was presented. The use of approximation formulas was demonstrated on the computational example. It was concluded that taking into account the elastic restraint of the edge of the cantilever wall (plate) in the thin-walled bar segment, and also the transverse and longitudinal stress variation gives more precise determination of the critical stress in local buckling. That contributes to improvement in the representation of the thin-walled element behaviour in the computational engineering model. The critical stress determined in the way described in the study can also help to more accurately determine of effective widths of cantilever walls which are under different loads.
\end{abstract}

Keywords: thin-walled bars, open section, cantilever plates, elastic restraint, longitudinal stress variation

Przestano do redakcji:30.05.2015

Przyjęto do druku:1.12.2015

DOI: $10.7862 / \mathrm{rb} .2015 .167$ 